\title{
BELAZARTE E MALAZARTE CARAS DE UM INTELECTUAL FICCIONAL
}

\author{
André Piazera Zacchi \\ UFSC / CAPES
}

RESUMO: Entre 1923 e 1924 Mário de Andrade publica, na Revista América Brasileira, de periodicidade mensal, as Crônicas de Malazarte. Nelas, constrói três personagens com gostos, opiniões e afetos distintos: Malazarte, Belazarte e Mário. As vozes ficcionais no espaço da revista, falando da mais iminente contingência brasileira, são caras, estratégias de Mário para assumir posturas políticas, sem que ocupe o lugar convencionalmente atribuído ao intelectual (aquele que sabe a verdade e a enuncia). Caras é também o nome de um ensaio sobre Chaplin na revista Essírito Novo, no qual Mário de Andrade separa e reúne diretor, criador, ator e personagem, Charles Chaplin e Carlitos. A cara de Carlitos, ostensivamente ficcional, é uma força capaz de imobilizar o que é só movimento, o cinema. Mário de Andrade pensa dentro da ficção, distribui-se nas caras das personagens às quais dá voz, esquiva-se dos lugares de poder, logrando interromper sua tradição.

PALAVRAS-CHAVE: Mário. Intelectual. Caras.

\section{BELAZARTE AND MALAZARTE}

FACES OF A FICTIONAL INTELLECTUAL

ABSTRACT: Between 1923 and 1924 Mário de Andrade publishes the Chronicles of Malazarte in Revista América Brasileira. There, he builds three characters with different tastes, opinions and affections: Malazarte, Belazarte and Mário. The fictional voices in the space of the magazine are faces, speaking about the most imminent Brazilian contingency. These faces are Mário's strategies to stand in political positions, without occupying the place conventionally altributed to the intellectual (the one who knows the truth and enunciates it). Caras (Faces) is also the name of an essay about Chaplin in the magazine Espirito Novo, where Mário de Andrade separates and reunites director, creator, actor and character, Charles Chaplin and Charlie. Charlie's face, ostensibly fictional, is a force capable of immobilizing what is only movement, the cinema. Mário de Andrade thinks within the fiction, distributes himself in the faces of the characters to whom he gives voice, he evades of the power managing to interrupt its tradition.

KEYWORDS: Mário. Intellectual. Faces.

André Piazera Zacchi é doutorando do Programa de Pós-Graduação em Literatura na Universidade Federal de Santa Catarina. 


\section{BELAZARTE E MALAZARTE CARAS DE UM INTELECTUAL FICCIONAL}

\section{André Piazera Zacchi}

Quem escreve Belazarte, faz ouvir Malazarte. O narrador e personagem folclórico (Pedro Malasartes ${ }^{1}$ ), disseminado em contos pelo país, faz girar em torno de seu nome duas características importantes: a narrativa heroica da vitória e o uso de artifícios de malandragem e esperteza para alcançar seus objetivos pessoais. Malazarte é um herói, justiceiro, dotado de uma arte pouco ortodoxa, às vezes ilegal, às vezes imoral, para conseguir o que quer. ${ }^{2}$ Talvez daí se possa inventar uma origem para o nome que faz coincidir artifício, artimanha (arte) e um expediente moral ( $m a l$ ). Belazarte traz consigo Malazarte, não como antípoda ou antídoto ao mal, mas simplesmente como uma outra cara: o belo, ou seja, sua face estética. Ao lado das malas-artes, as belas-artes. Quem lê Belazarte, quem lê junto, pela ausência, Malazarte, lê também o hasard que o belo e o mal trazem como sufixo, graças à letra z que compõe azar. Acaso. A mise-en-scène que se abre ao acaso, com Belazarte e Malazarte, mas também com Macunaíma e Carlitos, produzindo caras que aparecem no seio da ficção e tem a potência de embaralhar as vozes e os lugares de exercício do poder.

Mário de Andrade já publicara dois dos Contos de Belazarte na revista América Brasileira, na coluna assinada por ele, intitulada, não por acaso, Crônicas de Malazarte. ${ }^{3}$ No primeiro texto da série, na edição n. 22 da revista, em outubro de 1923, Mário começa a dar os contornos desses dois personagens que o

\footnotetext{
${ }^{1}$ Personagem já presente nas literaturas espanhola e portuguesa antes da chegada à América, conforme elucida Luís da Câmara Cascudo (Contos Tradicionais do Brasil, Rio de Janeiro, Tecnoprint, 1967), sobrevive na tradição oral brasileira e aparece publicado em livro pela primeira vez no volume de Figueiredo Pimentel, Contos da Carochinha, de 1894. Graça Aranha escreve a peça intitulada Malazarte, em 1911, que se tornaria libreto para a ópera de Oscar Lorenzo Fernandez em 1931. Mario de Andrade escreveria o libreto para a ópera Pedro Malazarte de Camargo Guarnieri em 1932. O personagem também recebe versão cinematográfica com Mazzaropi em As Aventuras de Pedro Malasartes de 1960.

2 Foi a versão de Câmara Cascudo que serviu à análise antropológica de Roberto DaMatta, no capítulo "Pedro Malasartes e os paradoxos da malandragem", no qual elabora um personagem-tipo da narrativa nacional brasileira - Carnavais, Malandros e Heróis (Rio de Janeiro, Rocco, 1997). CASCUDO, Luís da Câmara. Seis aventuras de Pedro Malasartes. In: Contos tradicionais do Brasil. Rio de Janeiro: Tecnoprint, 1967.

3 As Crônicas de Malazarte foram publicadas entre outubro de 1923 e julho de 1924 na Revista América Brasileira (números 22 a 31), editada e publicada no Rio de Janeiro, dirigida por Elysio de Carvalho, disponíveis hoje na Hemeroteca Digital Brasileira da Biblioteca Nacional.
} 
acompanharão, inicialmente, nas crônicas mensais. Veremos que estarão presentes na literatura futura de Mário, como outras de suas caras.

\begin{abstract}
Malazarte, andejo impenitente, vai de povoado em povoado. Viaja sempre. Mesmo porque os homens se cansam com rapidez da alegria. A alegria é coisa monótona, cheia de si, desilusória até, pois é um fim, um "goal", seccionando a continuidade dessa vida evolutiva e transitória. Não se dá o mesmo com a tristeza que implica, estranhos a ela, uma paz e uma felicidade ulteriores. Ninguém se consola da alegria com a visão de males futuros. A alegria é eminentemente extática. Só a dor é dinâmica. Tende para. (...)

Malazarte sabe disso, então viaja para não se tornar cansativo, portanto inútil e desestimado.

Por onde passa deixa um raconto engraçado, uma façanha burlosa e... E os homens cismativamente põem os olhos na estrada por onde ele se foi. É a saudade.

(...)

Estão percebendo? Em Portugal deseja-se a presença. Malazarte, porém, nasceu no Brasil. Chega. Faz uma estrepolia. Vai-se embora. Desdobra-se, porém, como um deus, em milhares de imagens melhoradas. Na realidade ele fica. Digo "na realidade" pois nada existe de mais real que as criaturas de nossa fantasia. Eis a saudade pois, que ao influxo desta imaginativa amazônica, se extasia em si e fica à beira da estrada a cismar. Como efeito, Malazarte continua presente porque a fantasia o reconstrói e alinda. ${ }^{4}$
\end{abstract}

Malazarte sabe que sua alegria cansa, que as metas se esgotam sozinhas, que os objetivos declarados matam (seccionam) a vida. Por isso viaja e é sua ausência que dá lugar à saudade brasileira, distinta da portuguesa, pois não é desejo de presença mas a cisma pela falta e a então existência fantasmática, fantasiosa. O lugar de Malazarte é a ficção, seu espaço de jogo, o registro enunciador de suas "verdades." Ele é o "dono" das crônicas e na fantasia está sua realidade mais potente e linda.

Há porém, uma quarta personagem, Pollux de Malazarte. Chama-se Belazarte e é a segunda mediante da tríade: mi bemol. Dá o modo menor. (...) Tudo isso é profundamente verdade: Malazarte e Belazarte, que darão amodalidade destas crônicas, são amigos íntimos. Nada há porém mais discordante que estes senhores. Malazarte é irônico, brincalhão e ilusionista. cabotino também, por que não? Belazarte é rabugento. Tristonho e realista. Sentimental às vezes, por que não? Ambos terrestremente brasileiros. Tão diversos e tão braços-dados! Assim é. Só numa coisa eles se igualam: é na mentira. Nela são ambos geniais. (...)

Malazarte sonha. Quando reconta seus sonhos desparze em torno de tais ópios de ilusão que a turba vê o que ele contou: progressos de povo, glorias de arte, gozos de religião e de amor. Quando parte em seguida, a turba continua a ver na aldeia a

${ }^{4}$ ANDRADE, Mario. Chronicas de Malazarte I. Revista América Brasileira, n. 22, p. 288. Rio de Janeiro, outubro de 1923. 
grande cidade industrial. Nela o imperador governa com cetro forte e sapientíssimo. nas arquiteturas, nas praças, nos museus e bibliotecas os melhores exemplos da arte humana se conservam.

(...) Mas Belazarte fala. Nas casas tijoladas da aldeia vê taperas. O imperador torna-se um presidente. As artes morem decrépitas porque não há mais gênios. Amor é carne e carne só. Tupan adormeceu gelado entre as neves dos Andes. O país vae mal. Vai muito mal! A natureza nos vence. E a villa, a enseada, os campos fecundos se uniformizam no deserto que não flore ou na floresta que ninguém vencerá. (...) Tudo mentira. Como também a visão de Belazarte. Malazarte acredita na sábia poesia dos Upanishades. Belazarte provou da sábia copa de Salomão. Malazarte é cigano e viaja. Belazarte é carpinteiro e fica. (..) Eu receptáculo das confidências de ambos, darei conta delas aos leitores da America Brasileira. ${ }^{5}$

Belazarte é Pollux de Malazarte, seu irmão gêmeo, mas com características outras, outra cara na qual sobressaem a tristeza, a rabugice, a desesperança. Um pensador ficcional de outro tipo, que encara os fatos e a vida com pessimismo. Ao lado de um "mi maior" Malazarte, um "mi bemol", Belazarte. Se ele fica é porque é triste, e a tristeza movimenta. "Tende para". De um jeito ou de outro: o movimento. Seja pela saudade ou pela tristeza, pela viagem ou pela permanência. Mário personagem se coloca como receptáculo, como escritor de suas confidências, porque aí se armam os três intelectuais que irão travar suas lutas, entre si e contra os inimigos que por bem entenderem enfrentar.

Em 1934, seria enfim publicado em volume os contos de Belazarte. ${ }^{6}$ Só depois de dez anos receberiam certa estabilidade, em 1944, quando Mário retira da edição o Caso em que entra bugre e insere O Besouro e a Rosa. Numa nota explicativa da primeira edição, Mário também confunde Malazarte e Belazarte, atribuindo ao segundo as crônicas do primeiro:

Estes contos foram planejados pra servirem de intermédios a umas Crônicas de Belazarte, publicadas na América Brasileira. De cinco em cinco crônicas, um se intercalava. Foram assim publicados os dois primeiros, 'O besouro e a Rosa' (América Brasileira de fevereiro de 1924) e 'Caim, Caim, e o resto' (América Brasileira de julho de 1924). Depois, impulsos de camaradagem me obrigaram a sair da revista, que aliás morreu logo.?

No livro que reúne os contos chama à atenção a frase, em itálico, que abre cada um deles: "Belazarte me contou:" Assim, os contos são de Belazarte, que assume a função de narrador e personagem, é ele quem conta as histórias do

\footnotetext{
${ }^{5}$ Ibidem, p. 288-289.

${ }^{6}$ ANDRADE, Mario de. Os contos de Belazarte. 6. ed. São Paulo, Martins, 1973.

7 Observação feita por Mário na nota "Bibliografia" da Edição publicada pela Editora Piratininga, destacada por Aline Nogueira Marques em publicação no site do IEB. MARQUES, Aline Nogueira. Uma edição fidedigna à luz de um manuscrito: os contos de Belazarte.
} 
livro para um narrador em segundo grau, que aparentemente é quem escreve o texto. $\mathrm{O}$ artifício expõe pelo menos duas camadas em constante contato e troca: o narrador que ouve e escreve (conta ao leitor) e Belazarte, que havia contado aquelas histórias ao narrador. Podíamos chamar esse narrador em segundo grau de Mário de Andrade. Belazarte caracteriza seu interlocutor com dados biográficos de Mário: "Você é músico, e do conservatório grande lá da avenida São João, por isso há de se divertir com o caso..." ${ }^{8}$ Há ainda o Mário autor, função-autor, poeta, modernista, intelectual, crítico de música, cinema, literatura, autor também epistolar, que nas trocas com Drummond fala sobre os contos que são seus e de Belazarte. Uma simples oração no início dos contos evidencia essa multiplicidade de vozes que falam juntas, cada uma com seus aspectos. Talvez o interesse do autor fosse mesmo dar uma coesão ao conjunto, justificando a publicação em volume, mas, independentemente de seus objetivos, não se oblitera a alteridade emergente:

\begin{abstract}
Quase todas as histórias acabam com o refrão Fulano foi muito infeliz. Fulano foi muito feliz vem em duas histórias só, são felizes uma bêbeda esquecida do mundo Nízia Figueira e um moço bobo. Bobo no sentido da medicina popular. Eu estou achando que o defeito de certas histórias de Belazarte é que estão um pouco pesadonas de tão compridas porém contra isso não posso nada. É estilo de Belazarte e não meu. Por mais que considere artisticamente esses casos não posso diminuí-los! Não são meus e palavra que não estou fazendo blague. São de Belazarte figura imodificável. ${ }^{9}$
\end{abstract}

Alteridade estranhada por Drummond. Afinal, quem era o contista, Mário ou Belazarte? Quem os escreve? Teria o contista personagem Belazarte adquirido figura própria, deixando Mário de mãos atadas? Ou seria Belazarte uma das caras de Mário, e da qual não queria abrir mão? Carlos lhe responde:

\footnotetext{
Mas me parece que você é que está errado quando diz certas histórias do Belazarte estão de fato meio compridas; estão, porém você não pode consertá-las porque 'é estilo de Belazarte e não meu'. Ora, sebo, seu Mário, então isso é coisa que se diga? Quem escreve os contos de Belazarte é você ou é Belazarte? ${ }^{10}$
}

\footnotetext{
${ }^{8}$ ANDRADE, Mario de. Os contos de Belazarte, op. cit., p. 63.

9 ANDRADE, Carlos Drummond. Carlos \& Mário: correspondência de Carlos Drummond de Andrade e Mário de Andrade. Org. Lélia Coelho Frota. Apresentação e notas às cartas de Mário de Andrade de Carlos Drummond de Andrade. Apresentação e notas às cartas de Carlos Drummond de Andrade de Silviano Santiago. Rio de Janeiro: Bem-Te-Vi Produções Literárias, 2002, p. 262.

10 Ibidem, p. 269.
} 
Belazarte, uma voz ficcional consistente, com estilo próprio, imodificável pelo autor, é também a viabilidade de uma fala cara a Mário que, através dessa voz, consegue se inscrever. Há no livro de contos uma notável aposta na escritura da fala cotidiana, da oralidade, uma ênfase na figura desse contador oral, que controla os sabores, as reações, os desenhos psicológicos e antropológicos a partir de seu mundo, de seu lugar de narrador ficcional, também caracterizado no próprio texto que enuncia. Os preconceitos de classe, a visão de mundo, os desejos, são todos dele, Belazarte, e Mário de Andrade não pode senão escrevê-los, fazê-los viver no papel de um livro de contos, histórias, livro de ficção.

Esse expediente já vem desde as crônicas de um Malazarte de opiniões próprias e também discordantes das de Mário. Discutem, por exemplo, sobre o filme O Gabinete do Dr. Caligari (1920). Malazarte não gostou do filme, Mário sim. E as duas vozes se misturam. Mário aproveita a voz de Malazarte para falar mal de expedientes artísticos estetizantes e dos teóricos generalizantes. Temse de estar atento para a sutil mudança das vozes na mesma crônica.

Malazarte não gosta de Rembrandt nem das luzes artificiais do mestre holandês. Ora bolas! eu quero a luz do Sol, que, mesmo sem falar de insolações, produz o mais estranho dos paraísos artificiais, o dia! E Rembrandt já passou. Eu me transformo. Pensas então que ficaria atrás? Qual! Sou modernizante. Não conto mais a história da panela, conto a alegria muscular dos cowboys e me fiz empresário cinematográfico. Tanto falaram no "Gabinete do Dr. Caligari" que aluguei o filme. Porcaria! Rembrandt legítimo. Mistérios, doenças, nenhuma insolação. Porcaria! (...)

Malazarte não tem razão. Isso acontece às pessoas que pregam teoria.

(...)

Malazarte avança, mas erra às vezes. Errou bastante não gostando do "Gabinete do Dr. Caligari". Uma das melhores obras até agora aparecidas no cinema. Representada por um grupo admirável de artistas. (...) Malazarte é que não teve razão de detestar o filme. Caçoando êle murmura: Não tenho razão, mas tive senso-comum. E nada mais delicioso que afogar-se na inconsciência transcendental do senso-comum. ${ }^{11}$

Nessas distâncias que se estabelecem, entre Malazarte e Belazarte, entre Belazarte e Mário, entre Mário e Mário, nota-se, justamente, uma contiguidade, e não a presença de opostos. Uma alteridade em série, ritmada e totalmente linguajeira, construída pela caráter ficcional da linguagem. Por diversos motivos os Contos de Belazarte podem ser considerados um ensaio para a escritura de Macunaíma, ainda que tenham sido publicados em livro depois do herói sem ne-

${ }_{11}$ ANDRADE, Mario. Chronicas de Malazarte III. Revista América Brasileira n. 24, p. 340. Rio de Janeiro, dezembro de 1923. 
nhum caráter. ${ }^{12} \mathrm{O}$ uso da oralidade, das expressões populares enfim escritas em livro, e com isso a possibilidade dos personagens falarem uma "língua brasileira", uma estrutura narrativa não-heroica, ou anti-heroica, desativadora dos sucessos trágicos, ou seja, em Belazarte não se narram vitórias. Já em Macunaíma também concorrem alteridades entre os diversos protagonistas que sobrevivem no texto de Mário: preto retinto, índio, filho do medo, feio, preguiçoso, esperto, egoísta (um tipo-malazarte), príncipe, lindo, fogoso, imperador, herói. Ou seja, de tantas caras distinguíveis (caráter), o herói não tem, afinal, nenhum. Mário abre a possibilidade de sair do elemento moral (o bom ou mau caráter) para os múltiplos personagens ficcionais (character), máscaras de Macunaíma que podem, em cada esquete narrativo local, colocar em xeque a narrativa de construção de um herói nacional vitorioso.

"Acabou-se a história e morreu a vitória", diz o epílogo de Macunaíma13, reiterando a falência da narrativa heroica e, não podia ser diferente, da narrativa nacional heroica, daquela que busca uma redenção ou um sucesso à nação após as sucessivas peripécias. Nesse diapasão heroico, o presente histórico é sempre um estado intermediário e faltoso, que sobrevive na espera de uma redenção apocalíptica. Se o autor de Macunaíma propõe que o fim da história é também o fim da vitória, encaminha pelo menos duas propostas para o presente (narrativo inclusive): não há revelação a se esperar para o fim da história e, se há alguma vitória, ela só acontece enquanto a história dura, só poderemos celebrar sua própria duração. E a duração da história é apenas a manutenção da ficção, da condição de linguagem na qual a história se verte e ao mesmo tempo se abre. Mário de Andrade está menos preocupado em propor uma história salvadora do Brasil (que até pode ser uma de suas caras) do que desativar poderes que põem em cena sempre a mesma máquina ficcional sem ruídos, sem resto, estabilizadora. Mário queria mais. E encontrou caminhos diferentes, alguns de construção, outros de inoperância, desativação. Nos contos de Belazarte e em Macunaíma evidencia-se o paradoxo: Mário monta uma narrativa que desmonta o destino, a meta, a vitória.

Mário sabe que tão importante quanto potencializar a ficção e a própria linguagem, evidenciando-a como tal, é interpor várias vozes narrativas, multiplicando as caras do enunciador da ficção. O intelectual pode, assim, ser qualquer uma dessas vozes, Belazarte, Malazarte, Macunaíma, Mário de Andrade, diminuindo sua condição de sujeito ativo, com boas ideias, com uma crítica aguda, capaz de produzir consciência nas massas, para assumir o lugar efêmero,

${ }^{12}$ ANDRADE, Mário de. Macunaíma: o herói sem nenhum caráter. Edição crítica de Telê Porto Ancona Lopez. Rio de Janeiro: Livros Técnicos e Científicos, 1978.

13 Ibidem, p. 121 
extremamente frágil, e, paradoxalmente, extremamente efetivo do intelectual ficcional inoperante, ou melhor, uma ficção que possa travar, nem que seja por instantes, as máquinas de consenso que sustentam um exercício de poder.

A estratégia de Mário de Andrade apareceria futuramente descrita por Michel Foucault, na discussão que trava com Gilles Deleuze sobre a relação entre os intelectuais e o poder, na qual propõe o nascimento de um outro intelectual, distinto dos tradicionais, fora do lugar discursivo a eles atribuído no mesmo exercício de poder que tentariam evidenciar, revelar:

Parece-me que a politização de um intelectual tradicionalmente se fazia a partir de duas coisas: em primeiro lugar, sua posição de intelectual na sociedade burguesa, no sistema de produção capitalista, na ideologia que ela produz ou impõe (ser explorado, reduzido à miséria, rejeitado, "maldito", acusado de subversão, de imoralidade, etc.); em segundo lugar, seu próprio discurso enquanto revelava uma determinada verdade, descobria relações políticas onde normalmente elas não eram percebidas. Estas duas formas de politização não eram estranhas uma em relação à outra, embora não coincidissem necessariamente. Havia o tipo do intelectual "maldito" e o tipo do intelectual socialista. Estas duas formas de politização facilmente se confundiram em determinados momentos de reação violenta do poder, depois de 1848, depois da Comuna de Paris, depois de 1940: o intelectual era rejeitado, perseguido, no momento mesmo em que as "coisas" apareciam em sua "verdade", no momento em que não se devia dizer que o rei estava nu. $\mathrm{O}$ intelectual dizia a verdade àqueles que ainda não a viam e em nome daqueles que não podiam dizê-la: consciência e eloquência. Ora, o que os intelectuais descobriram recentemente é que as massas não necessitam deles para saber; elas sabem perfeitamente, claramente, muito melhor do que eles; e elas o dizem muito bem. Mas existe um sistema de poder que barra, proíbe, invalida esse discurso e esse saber. Poder que não se encontra somente nas instâncias superiores da censura, mas que penetra muito profundamente, muito sutilmente em toda a trama da sociedade. Os próprios intelectuais fazem parte deste sistema de poder, a idéia de que eles são agentes da "consciência" e do discurso também faz parte desse sistema. O papel do intelectual não é mais o de se colocar "um pouco na frente ou um pouco de lado" para dizer a muda verdade de todos; é antes o de lutar contra as formas de poder exatamente onde ele é, ao mesmo tempo, o objeto e o instrumento: na ordem do saber, da "verdade", da "consciência", do discurso. E por isso que a teoria não expressará, não traduzirá, não aplicará uma prática; ela é uma prática. Mas local e regional, como você diz: não totalizadora. Luta contra o poder, luta para fazê-lo aparecer e feri-lo onde ele é mais invisível e mais insidioso. Luta não para uma "tomada de consciência" (há muito tempo que a consciência como saber está adquirida pelas massas e que a consciência como sujeito está adquirida, está ocupada pela burguesia), mas para a destruição progressiva e a tomada do poder ao lado de todos aqueles que lutam por ela, e não na retaguarda, para esclarecê-los. Uma "teoria" é o sistema regional desta luta. ${ }^{14}$

${ }^{14}$ FOUCAULT, Michel. Microfísica do Poder. Organização, introdução e revisão técnica de Roberto Machado. Rio de Janeiro: Graal, 1979, p. 41. 
Mário oscila entre travar a luta colocando-se na posição de intelectual esclarecedor (as massas precisam dele para saber) ou colocar-se como porta-voz da resistência, lutando contra as formas de poder, em textos nos quais se multiplica como personagem intelectual, enquanto intelectual que quer esvaziar o lugar onde o exercício do poder poderia encontrá-lo, ou seja, a verdade, mascarando-se através de múltiplas vozes discursivas (mentirosas). Malazarte chama Mário de intelectual, orientando para que se afaste dos desejos dos leitores, o que é aprovado, já que o escritor das crônicas, numa piscada anacrônica a Foucault, não se inclina a dirigir consciências.

\begin{abstract}
Deu-se agora um fato muito importante na minha vida: fiz trinta anos. Que tenho eu com isso! dirá o leitor que sabe livros e se preza. Com efeito, não tem nada. Eu é que tenho. Não basta? Malazarte sempre me repete: Intelectual, nunca te preocupes com preceituário dos leitores. São vaidades. Leitor que se preza é absolutamente desprezível. Esta maneira de pensar de Malazarte me agrada, embora lembre Wilde - e eu não seja grande admirador de "Intenções". (..)

Tenho um ginásio imaginário na cabeça em que os alunos estudam filosofia em Nietzsche, latim em Petronio, psicologia em Geraldy e Bourgett. As tragédias que adoto são de Bataille, Ibsen, Maeterlinck e Sudermann. Ali se aprende o português em Guerra Junqueiro, em Silvio Romero e na Revista da Lingua Portuguesa. Deste jeito meus alunos se aborrecem de coisas pernósticas, de coisas inutilmente nebulosas e simbólicas, de maus versos, maus romances, e nunca mais quererão escrever mal o português. Mas é um ginásio apenas imaginário. Não tenho inclinação para diretor de consciências, como se vê. ${ }^{15}$
\end{abstract}

Mas qual seria então a ação intelectual de Mário nessas crônicas? Uma delas é falar de si. Porque aí estaria falando dos outros. Não naquilo que é necessário e útil pois, afirma, nada é útil. Fala de si, escreve Eu, e esse Eu é uma cara, uma máscara, apropriável por qualquer um, já que os homens são, a despeito de seus narizes e morais, universais. O intelectual produz alteridade e identificação, já que as máscaras são intercambiáveis e referem-se a um "si" que não existe mais, por trás da cara não há ninguém individualizável, há apenas o comum.

Dirão também que estou a falar de mim? estou. Mas, embora já me aborreça o paradoxo, falar de mim é falar dos outros também. Mas creio que não sou lá muito são de espírito. Volto a afirmar essa verdade porque me lembro das palavras de Shestov: o homem são de espírito, inteligente ou imbecil, na realidade não fala de si, mas do que pode ser necessário e útil aos outros. Mas, pergunto eu, quem é são de espírito? Que coisa é útil na Terra? Ademais, falar de si, falar dos outros... Tudo

${ }^{15}$ ANDRADE, Mario. Chronicas de Malazarte II. In: Revista América Brasileira n. 23, p.318. Rio de Janeiro, novembro de 1923. Disponível na Hemeroteca Digital Brasileira, da Biblioteca Nacional. Grifo meu. 
o mesmo. Nem nós, homens diferentes deste mundo, somos tão diferentes assim. A questão se limita a volume de narizes e morais. Qual a diferença entre os homens? Um tem dois milímetros quadrados menos de nariz, outro maior cubagem na moral. Mas todos nós temos nariz e moral. E é por causa destes recipientes que quando digo Eu, o leitor entende tratar-se dele. Por causa de termos sem exceção, moral e nariz, homens somos todos - um universal, como aprendi a dizer nessa fantasia linda e inútil, posta por vocês no departamento das ciências e por mim no departamento das malazartes, a Filosofia. ${ }^{16}$

Filosofia, coisa linda e inútil, mala-arte, se torna em seu pregador, Malazarte, coisa linda e inútil, no sentido de esclarecimento, reflexão, tomada de consciência, mas efetiva, na sua luta pontual de interrupção da engrenagem do poder. São intelectuais esses três, dentro da proposta que Mário antecipa a Foucault, para exercer um contra-poder. Com eles, Mário escritor amplia a área de manobra do pensamento, e da ação efetiva da palavra, qual seja, de exibir sua cara linguajeira, seu vazio essencial. Com Belazarte, Malazarte e Mário, Mário de Andrade pode falar de tudo, contradizer-se, assumir seus próprios paradoxos. Pode ser e, ao mesmo tempo, não ser. ${ }^{17}$

O epílogo de Macunaíma reforça essa ideia desativadora do poder que é usar-se de narradores ficcionais, inserindo a ficção na garantia de veracidade do relato. Porque, para esses intelectuais, ficção e verdade não se contrapõem, ao contrário, são forças que trabalham juntas para o franco dizer. Reaparece aqui Foucault, para nos definir o ficcional, sem firulas: "a nervura verbal do que não existe, tal como ele é". ${ }^{18}$ Potências da ficção, arma do intelectual. No epílogo, retomo, o narrador diz que recebeu a história de um papagaio, o único arconte das histórias de "nosso herói", como se dissesse, repetindo a fórmula de Belazarte: papagaio me contou:

Então o homem descobriu na ramaria um papagaio verde de bico dourado espiando pra ele. Falou:

- Dá o pé, papagaio.

${ }_{16}$ Ibidem, p. 318.

${ }^{17}$ Mário, embora discorde e faça força contra o surrealismo, aqui se encontraria com Murilo Mendes e seu Pós-poema, publicado em Poesia Liberdade de 1947: O anteontem - não do tempo mas de mim -/Sorri sem jeito/E fica nos arredores do que vai acontecer/Como menino que pela primeira vez põe calça comprida.//Não se trata de ilusão, queixa ou lamento,/ Trata-se de substituir o lado pelo centro./O que é da pedra também pode ser do ar./O que é da caveira pertence ao corpo;/Não se trata de ser ou não ser,/Trata-se de ser e não ser. Grifo meu.

${ }^{18}$ FOUCAULT, Michel. Ditos e escritos III - Estética: Literatura e Pintura, Música e Cinema. Rio de Janeiro, Forense Universitário, 2009, p.69. 
O papagaio veio pousar na cabeça do homem e os dois se acompanheiraram. Então o pássaro principiou falando numa fala mansa, muito nova, muito! que era canto e que era cachiri com mel- de-pau, que era boa e possuía a traição das frutas desconhecidas do mato.

A tribo se acabara, a família virara sombras, a maloca ruíra minada pelas saúvas e Macunaíma subira pro céu, porém ficara o aruaí do séquito daqueles tempos de dantes em que o herói fora o grande Macunaíma imperador. E só o papagaio no silêncio do Uraricoera preservava do esquecimento os casos e a fala desaparecida. Só o papagaio conservava no silêncio as frases e feitos do herói.

Tudo ele contou pro homem e depois abriu asa rumo de Lisboa. E o homem sou eu, minha gente, e eu fiquei pra vos contar a história. Por isso que vim aqui. Me acocorei em riba destas folhas, catei meus carrapatos, ponteei na violinha e em toque rasgado botei a boca no mundo cantando na fala impura as frases e os casos de Macunaíma, herói de nossa gente.

Tem mais não. ${ }^{19}$

Quem cantou na fala impura as frases e os casos de Macunaíma? A mesma fala impura (fala mansa, boa, traição das frutas) que povoava os contos de Belazarte? Um narrador totalmente ficcional que pôde abdicar das belas letras, lugar de poder contra o qual o Mário em várias instâncias se rebelara. O narrador conta a história do "herói de nossa gente" que ouviu de um papagaio, debochando do poder dos arcontes da literatura brasileira, que a queriam segundo modelos cristalizados há mais de século. Quem destila seus preconceitos de classe, seus desejos e sua visão do subúrbio senão o narrador Belazarte, dotado de vontades próprias e contra o qual Mário nada pode?

São as diversas caras de um intelectual, caras que se propõem algumas vezes resistir ao poder. Diversas caras, muitos caráteres, nenhum caráter. Produtor de intelectuais ficcionais, Mário valoriza a cara, a fachada, a semblância, diminuindo a importância do rosto enquanto elemento ligado a uma biografia, ao homem. Na leitura do filme The Kid, de Charles Chaplin, texto que Mário intitula "Caras", está proposta uma distinção entre cara e rosto. A primeira versão, publicada na revista Espírito Novo, embaralha as figuras do cineasta e do personagem, quase sempre atribuindo as criações a Carlito. Sobre essa versão, Mário rabisca, corrige para uma possível publicação na Revista Acadêmica em 1943, promovendo a distinção: o rosto é do criador Charles Chaplin e a cara de Carlito. O rosto está em movimento, como as pessoas, as gentes, e a cara está imobilizada, Carlito tem cara de desenho (parado, acrescenta Mário). As supressões ou acréscimos estão entre parênteses.

\footnotetext{
${ }_{19}$ ANDRADE, Mário de. Macunaíma: o herói sem nenhum caráter, op. cit.
} 
Carlito (Charles Chaplin) compôs uma cara decididamente caricatural e apesar disso bonita como arte. O que há de mais admirável na criação da cara de Carlito é que todo o efeito dela é produzido diretamente pela máquina fotográfica. ${ }^{20}$ Earlito (Charles Chaplin) conseguiu Ihe dar uma qualidade anticinegráfica, a que faltam enormemente as sombras e principalmente os planos. E é por isso, em principal que a cara dele é cômica em si, contrastando violentamente com os outros rostos que aparecem no écran e que a gente percebe como rostos da vida real.

Não falo que a cara composta por Earlito (Chaplin) não seja fotogênica, pelo contrário, é fotogeniquíssima. Porém é anticinegráfica, por isso que dá a sensação dum homem real com cara de desenho (parado), no meio de homens igualmente reais e com cara de gente mesmo (, de gente em movimento).

(...)

O retrato real de Chaplin, por mais que a gente simpatize com ele -por amarmos Carlito -, nos causa sempre um certo mal-estar. Nos sentimos roubados ou mistificados, porque para nós o rosto de Chaplin é a cara de Carlito. ${ }^{21}$

Mais do que falar de algum filme, Mário dedica seu artigo à criação e interpretação do ator, aliada à criação plástica do cineasta. Busca encontrar causas e explicações estéticas para o sucesso de Chaplin e para a identificação dos espectadores com o personagem Carlito. Tal separação, entre o ator/diretor criador e o personagem criatura só fica completamente estabelecida, como vimos, num segundo momento, na segunda versão. Na primeira, a cara de Carlito sobressaía, solução utilizada por Elie Faure em artigo publicado na revista L'Esprit Nouveau n. 06, lido e sublinhado por Mário de Andrade, conforme suas fichas de leitura. ${ }^{22} \mathrm{O}$ francês não faz menção a Chaplin. Mário, ao contrário, ensaia desde o artigo para Klaxon ${ }^{23}$, no qual comenta o filme The Kid, uma coexistência de Chaplin e Carlito. Voltando a Elie Faure, suas teses sobre Charlot encontram terreno fértil em Mário que as retoma em seus artigos, desde o ensaio "Ainda O garoto" para o n. 5 da Klaxon, de $1922^{24}$, até o artigo "Caras" para a Revista

${ }^{20} \mathrm{Na}$ versão datiloscrita enviada (ou pronta a enviar) para Murilo Miranda por ocasião da edição da revista Acadêmica, Mário trocou a expressão máquina fotográfica por máquina cinematográfica, conforme imagem disponível no trabalho de Paulo José da Silva Cunha - Carlito ou Chaplin? Da criação ao criador: um exemplo de reelaboração textual em "Caras", de Mário de Andrade. O mesmo autor publica um livro no qual compila os textos de Mário relativos ao cinema: ANDRADE, Mario de. No cinema. Organização de Paulo José da Silva Cunha. Rio de Janeiro, Nova Fronteira, 2010.

${ }^{21}$ ANDRADE, Mario de. No cinema. Organização de Paulo José da Silva Cunha. Rio de Janeiro, Nova Fronteira, 2010.

${ }^{22}$ Paulo José da Silva Cunha encontra no Fichário Analítico - série Manuscritos de Mário de Andrade, Arquivo Mário de Andrade, IEB/USP - duas fichas intituladas "Carlito" e "Cinema" (Ficha 5443 e 5446). In: CUNHA, Paulo José da Silva. Carlito ou Chaplin? Da criação ao criador: um exemplo de reelaboração textual em "Caras", de Mário de Andrade.

${ }^{23}$ ANDRADE, Mário de. Ainda O garoto. Artigo publicado em Klaxon: mensário de arte moderna, n. 5, São Paulo, 15 out. 1922.

${ }^{24}$ Ibidem. 
Espírito Novo de $1933 .{ }^{25} \mathrm{Na}$ leitura que faz de Faure, o brasileiro sublinha em seu exemplar a frase: "Charlot est un conceptualiste." Carlito, criador de conceitos, (odiosamente, maravilhosamente) teórico, sem sombra de dúvidas, intelectual:

J'ai lu, plus récemment, qu'il renonçait au cinéma. Cela, je ne l'ai pas cru. Celui qui pense, s'il continue de vivre, ne peut renoncer à penser. Et Charlot pense, si l'on me permet cet adverbe effroyable, cinématographiquement. Charlot ne peut se délivrer de sa pensée qu'en lui donnant le corps sensible où le hasard lui en fit situer le symbole. Ne vous y trompez pas. Charlot est un conceptualiste. C'est sa réalité profonde qu'il inflige aux apparences, aux mouvements, à la nature même, à l'âme des hommes et des objets. Il organise l'univers en poème cinéplastique et lance dans le devenir, à la manière d'un dieu, cette organisation capable d'orienter un certain nombre de sensibilités et d'intelligences et par elles, de proche en proche, d'agir sur tous les esprits. ${ }^{26}$

Importante ressaltar que, para Elie Faure, Carlito pensa, não pode renunciar a pensar. É um intelectual. Um intelectual faz de seu corpo sensível, cinematográfico, o lugar do pensamento, seu vórtice. Um demiurgo que organiza um universo como um poema plástico, "cineplástico" capaz de agir sobre os espíritos. É sua vontade declarada, de Elie Faure, fazer de Carlito um intelectual artista, um grande espírito humano, que constrói uma realidade nova. Mário, como já disse, tampouco aposta nessa potência de intelectual ativo, antes, vê em Carlito um intelectual que sobre o rosto do homem (Chaplin) propõe uma máscara, assim como Belazarte era uma de suas caras. Lembremos que para o autor de Belazarte a cara de Carlitos é anticinegráfica, é desenho parado, imobilidade, mas produzida pela máquina (fotográfica) e pela capacidade criativa de Chaplin. É uma cara que causa efeitos, cômicos inclusive, no seu paradoxo de imobilidade de desenho diante do movimento do homem, diante da imagem que é movimento. Quer dizer, para Mário, Chaplin é um intelectual que põe em cena a cara de Carlitos, e este, por sua vez, um intelectual que pode fazer o cinema parar. Por isso Mário arremata que há dois cinemas, um cinema-criação, cinema arte, no qual a cara e o rosto transitam entre a dualidade e a unidade, e outro, cinema da sensualidade, cinema comércio, onde impera a superfetação, um acréscimo da cara ao rosto por mero ajuntamento. ${ }^{27}$

${ }^{25}$ ANDRADE, Mario de. Caras. Artigo publicado na revista Espírito Novo, n. 01, Rio de janeiro, janeiro de 1934, usamos a versão com correções do próprio Mário, datiloscrita e publicada em ANDRADE, Mario de. No cinema. Org. Paulo José da Silva Cunha. Rio de Janeiro, Nova Fronteira, 2010.

${ }^{26}$ FAURE, Elie. Charlot. L'Esprit Nouveau, n. 06, mar. 1921.

${ }^{27}$ ANDRADE, Mario de. Caras. Artigo publicado na revista Espírito Novo n. 01, Rio de janeiro, janeiro de 1934. 
Sobre o termo "cara", Raul Antelo nos dá pistas para lermos, com Mário de Andrade lendo Carlitos, a cabeça como um ir e vir entre o singular e o plural. Rosto, no latim, poderia ser vultus, ausente nos animas e que incluiria um elemento moral. Para os gregos, doxa, "glória de Deus". E persona, a máscara teatral, deveria estar ligada a uma evidência biográfica. Cara, vindo do termo poético kára, podia ser uma saída para ler a história a contrapelo, para ver em Carlitos aquilo que escapa ao rosto glorioso, moral ou semi-falsificante. A cara de Carlitos é sua força, assim como a cara de Belazarte, de Malazarte, de Macunaíma. A montagem da cara, linguajeira ou plástica, como o lugar de convergência da história, do choque de forças, um lugar para seu novo arranjo.

\begin{abstract}
Mário de Andrade intitula sua leitura heroica e biopolítica de Carlito de "Caras", palavra vinda do termo poético grego kára, cabeça, que sobrevive em algumas línguas romances: bonne chère, em francês, significa bom acolhimento. Deste modo, do elemento mais individual passamos ao comunitário. Cara não deriva do latim, que preferia o significante vultus, o mesmo que perduraria no gótico wulthus. Mesmo Cícero era consciente de que os gregos usavam kára para indicar uma representação (desse significante, justamente, provém careta, no sentido de máscara) e preferia, no entanto, volto, inexistente nos animais, palavra que, a rigor, indica o elemento moral. Para significar, contudo, o rosto ou semblante, os gregos usavam dóxa, que significa a glória de Deus. Assim, no Velho Testamento, a glória (Kabod) indica a divindade em sua manifestação aos homens. Mas, ao mesmo tempo, para os gregos, o conceito de persona, a máscara teatral, vinculava-se exclusivamente a uma evidência confiável, de tal sorte que, quando se empreendia uma autobiografia, não se podia prescindir da biografia, assim como não havia biografia sem história. Na cara convergem, pois, os vetores contraditórios da história. ${ }^{28}$
\end{abstract}

Carlitos é um herói para Mário, mas um herói criado a partir do rosto de Chaplin e que consegue imobilizar o que é só movimento, o cinema. Uma maneira de emperrar a máquina cinema-comércio, colocando em funcionamento a máquina criativa-artística, a máquina ficcional vinculada com a mais profunda realidade, ou melhor, com a mais profunda (re)montagem da realidade.

De certa forma, no ensaio Caras, Mário está dizendo que a criação de Chaplin, Carlito, é E não é Chaplin, mas encontrou uma cara própria, autônoma, imodificável, potente. Carlito é um intelectual, pensa cinematograficamente, imobiliza uma cara no cinema de rostos, mas, por ser e não ser Chaplin, não se trata de adição, superfetação. Assim também Mário, voltando sempre na figura

${ }^{28}$ A fala de Raul Antelo na Casa Rui Barbosa em novembro de 2015 foi disponibilizada no Youtube: Política e cultura: Mário de Andrade, também conhecido como Macunaíma. 
de Carlitos, bem como em seus intelectuais ficcionais, Belazarte e Malazarte, que são Mário mas também não o são, monta algumas caras, centros de resistência e embaralhamento das forças que exercem o poder.

Tudo isso é domínio de lenda. Imaginações! Malazartismo!

Malazartismo? Belazarte me olha e me saúda. Ergue aquele chapeuzinho curto de Carlito, que deu para usar. - Mário, um cigarro. - Perdoa Belazarte, ainda não te vira! Ele acende o cigarro. Atira-o fora, distraído. Queima o dedo e fuma o pau do fósforo. Saúda outra vez, sacode os ombros. Vai-se embora. Penso: Belazarte nunca fuma. Por quê agora fumou? 